\title{
Impact of updated traffic emissions on HONO mixing ratios simulated for urban site in Houston, Texas
}

\author{
B. H. Czader, Y. Choi, X. Li, S. Alvarez, and B. Lefer \\ Department of Earth and Atmospheric Sciences, University of Houston, Houston, TX, USA \\ Correspondence to: B. H. Czader (bczader@uh.edu)
}

Received: 10 July 2014 - Published in Atmos. Chem. Phys. Discuss.: 20 August 2014

Revised: 4 December 2014 - Accepted: 10 December 2014 - Published: 5 February 2015

\begin{abstract}
Recent measurements in Houston show that HONO traffic emissions are $1.7 \%$ of $\mathrm{NO}_{\mathrm{x}}$ emissions, which is about twice the previously estimated value of $0.8 \%$ based on tunnel measurements in 2001 . The $0.8 \%$ value is widely used to estimate mobile emissions of HONO for air quality modeling applications. This study applies the newly estimated $\mathrm{HONO} / \mathrm{NO}_{\mathrm{x}}$ ratio in the WRF-SMOKE-CMAQ modeling system and estimates the impact of higher HONO traffic emissions on its mixing ratios. Since applied emission inventory resulted in overestimates of $\mathrm{NO}_{\mathrm{x}}$ mixing ratios and because HONO emissions and chemical formation depend on the magnitude of $\mathrm{NO}_{\mathrm{x}}$, thus, before proceeding with $\mathrm{HONO}$ emission modifications emissions of $\mathrm{NO}_{\mathrm{x}}$ were adjusted to reflect current emission trends. The modeled mixing ratios of $\mathrm{NO}_{\mathrm{x}}$ were evaluated against measured data from a number of sites in the Houston area. Overall, the $\mathrm{NO}_{\mathrm{x}}$ mean value dropped from $11.11 \mathrm{ppbv}$ in the base case to $7.59 \mathrm{ppbv}$ in the $\mathrm{NO}_{\mathrm{x}}$-adjusted case becoming much closer to the observed mean of $7.76 \mathrm{ppbv}$. The index of agreement (IOA) is improved in the reduced $\mathrm{NO}_{\mathrm{x}}$ case $(0.71$ vs. 0.75$)$ and the absolute mean error (AME) is lowered from 6.76 to 4.94. The modeled mixing ratios of $\mathrm{HONO}$ were evaluated against the actual observed values attained at the Moody Tower in Houston. The model could not reproduce the morning HONO peaks when the low $\mathrm{HONO} / \mathrm{NO}_{\mathrm{x}}$ ratio of 0.008 was used to estimate HONO emissions. Doubling HONO emissions from mobile sources resulted in higher mixing ratios, and the mean value increased from 0.30 to $0.41 \mathrm{ppbv}$ becoming closer to the observed mean concentrations of 0.69 but still low; AME was slightly reduced from 0.46 to 0.43 . IOA for simulation that used the 2001 emission values is 0.63 while for simulation with higher HONO emission it increased to 0.70. Increased HONO emissions from mobile sources re-
\end{abstract}

sulted in a $14 \%$ increase in $\mathrm{OH}$ during morning time at the location of the Moody Tower and $3 \%$ when averaged over an urban area. The increase calculated for daytime was 7 and $1 \%$ for the Moody Tower and the urban area, respectively. The impact on ozone was found to be marginal. This study results shed light on the underestimated $\mathrm{HONO}$ and $\mathrm{OH}$ in the morning from global/regional chemical transport models with the typical emission of $0.8 \% \mathrm{HONO}$ emission out of the total $\mathrm{NO}_{\mathrm{x}}$ emissions.

\section{Introduction}

Photolysis of nitrous acid (HONO) is an important source of hydroxyl radical $(\mathrm{OH})$. $\mathrm{OH}$ plays a crucial role in the oxidation of volatile organic compounds (VOCs) leading to the formation of ozone and secondary organic particulate matter. Main sources of $\mathrm{OH}$ are photolysis of ozone, formaldehyde, alkenes, and nitrous acid (Elshorbany et al., 2009; Mao et al., 2010; Kim et al., 2014). Photolysis of ozone and formaldehyde are the most important sources of $\mathrm{OH}$ during midday and afternoon hours; however, the highest contribution to radical production during early morning hours comes from photolysis of HONO (e.g., Perner and Platt, 1979; Harris et al., 1982; Czader et al., 2012, 2013).

HONO can be either formed through chemical reactions or emitted to the atmosphere from combustion processes. Among the most known chemical sources of HONO is the gas-phase formation from the reaction between $\mathrm{OH}$ and nitric oxide (NO) (Pagsberg et al., 1997) and the heterogeneous formation on surfaces from the hydrolysis of nitrogen dioxide $\left(\mathrm{NO}_{2}\right)$ (Kleffmann et al., 1998; Finlayson-Pitts et al., 2003). Other chemical sources of HONO are described else- 
where (Kleffmann, 2007; Kleffmann et al., 2005; George et al., 2005; Stemmler et al., 2006, 2007; Crowley and Carl, 1997; Li et al., 2008, 2009; Carr et al., 2009; Amedro et al., 2011). Emissions of HONO from traffic were estimated by Kirchstetter et al. (1996) and Kurtenbach et al. (2001), who performed tunnel studies and reported exhaust emission ratio of $\mathrm{HONO}$ to $\mathrm{NO}_{\mathrm{x}}$ in a range of $0.003-0.008$. The value of 0.008 is used in the Community Multiscale Air Quality (CMAQ) model to calculate HONO emissions from mobile sources (Foley et al., 2010) as well as in other models, for example, in a box model employed to study HONO sources in Houston (Wong et al., 2013). The relative contribution of HONO emissions from traffic to other sources when using the HONO to $\mathrm{NO}_{\mathrm{x}}$ ratio of 0.008 is about $9 \%$ based on simulations for eastern US (Sarwar et al., 2008). For high $\mathrm{NO}_{\mathrm{x}}$ areas in China $\mathrm{Li}$ et al. (2011) calculated as high as $26 \%$ contribution of HONO emissions to its total sources, but they could not reproduce the high morning peak values of HONO associated with traffic emissions. Czader et al. (2012) studied HONO formation for Houston conditions and also applied the $0.008 \mathrm{HONO} / \mathrm{NO}_{\mathrm{x}}$ ratio to estimate $\mathrm{HONO}$ emissions. In addition to default sources of HONO present in CMAQ, they implemented photolytic HONO formation; however, on many occasions the peak morning values continued to be underpredicted by the model. Recent measurements performed in Houston in 2009 show that the observed $\mathrm{HONO} / \mathrm{NO}_{\mathrm{x}}$ emission ratio is 0.017 (Rappenglueck et al., 2013), which is about twice as high as previously reported and implemented in CMAQ modeling system. The impact of using higher HONO emissions in air quality modeling applications has not been evaluated. Therefore, in this work HONO emissions from mobile sources will be doubled to reflect the newly reported $\mathrm{HONO} / \mathrm{NO}_{\mathrm{x}}$ emission ratio and the impact of higher HONO traffic emissions on its mixing ratios will be estimated in the WRF-CMAQ modeling system. The impact of increased $\mathrm{HONO}$ on the $\mathrm{OH}$ and $\mathrm{O}_{3}$ will also be investigated in this study.

In air quality applications HONO is derived from the total $\mathrm{NO}_{\mathrm{x}}$ reported in an emission inventory, and chemical formation of HONO is directly related to $\mathrm{NO}$ and $\mathrm{NO}_{2}$ mixing ratios; therefore, HONO predictions by air quality models depend on how well the model captures emissions of $\mathrm{NO}_{\mathrm{x}}$. Czader et al. (2012) pointed out that the correlation between measured and simulated HONO values increased significantly when data points with wrong $\mathrm{NO}_{2}$ prediction were ignored and only data for which $\mathrm{NO}_{2}$ values were simulated within $70 \%$ of the measured value were considered. Therefore, accurate estimation of $\mathrm{NO}_{\mathrm{x}}$ in air quality models is crucial to properly simulate HONO mixing ratios. Previous studies used remote sensing and in situ surface observations to analyze accuracy of $\mathrm{NO}_{\mathrm{x}}$ emissions and indicated that the National Emission Inventory (NEI) has large uncertainty in emissions in urban areas (Choi et al., 2012; Choi, 2014). Of particular, Choi (2014) stated that both NEI2005 and NEI2008 have significant $\mathrm{NO}_{\mathrm{x}}$ overestimates in Hous- ton. Thus, in this study, before proceeding with modifications of $\mathrm{HONO}$ emissions, $\mathrm{NO}_{\mathrm{x}}$ emissions will be adjusted using the U.S. Environmental Protection Agency (EPA) annual trend values and the absolute amounts of simulated surface $\mathrm{NO}_{\mathrm{x}}$ concentrations will be evaluated.

\section{Methodology}

Meteorological parameters were derived with the Weather Research and Forecasting (WRF) model version 3.5 (Skamarock and Klemp, 2008). NCEP North American Regional Reanalysis (NARR) data provided by the NOAA/OAR/ESRL PSD (available at http://www.esrl.noaa. gov/psd/) were utilized to initialize WRF simulations. The 2008 National Emission Inventory (NEI2008) generated by the Environmental Protection Agency (EPA) was processed with the Sparse Matrix Operator Kernel Emissions (SMOKE) system to obtain gridded, chemically and temporally resolved emission files ready to use in an air quality model. The air quality simulations were performed with the three-dimensional Community Multiscale Air Quality (CMAQ) model (Byun and Schere, 2006) version 5.0.1 with the Carbon Bond 05 chemical mechanism and aerosol 5 module (cb05tucl_ae5_aq).

Simulations were performed for a domain with $4 \mathrm{~km}$ grid resolution covering southeast Texas, with 84 grid cells in east-west direction, 66 grid cells in south-north direction, and 27 vertical layers. The boundary conditions were obtained from the University of Houston air quality forecasting system (http://spock.geosc.uh.edu) from a larger domain with $12 \mathrm{~km}$ grid resolution, 150 grid cells in east-west direction and 134 grid cells in south-north direction. Initial conditions were also obtained from the air quality forecasting results from the nested south-east Texas domain. Simulations were performed for the month of September 2013, during which the DISCOVER-AQ campaign took place in Houston providing many different meteorological and chemical measurements that could be utilized for model evaluation.

\subsection{Adjusting $\mathrm{NO}_{\mathrm{x}}$ and $\mathrm{HONO}$ emissions}

Previous studies used remote sensing and in situ surface observations to analyze accuracy of $\mathrm{NO}_{\mathrm{x}}$ emissions and pointed to the fact that the National Emission Inventory (NEI) has large uncertainties in emissions for urban areas (Choi et al., 2012; Choi, 2014). Of particular, Choi (2014) pointed out that both NEI2005 and NEI2008 might have significant overestimates of $\mathrm{NO}_{\mathrm{x}}$ emissions in Houston even with the consideration of the uncertainties caused from other chemical and physical processes. Adequate estimation of $\mathrm{NO}_{\mathrm{x}}$ emissions is critical for properly predicting HONO mixing ratios.

Since our simulations employed NEI2008 there was a need to adjust emissions to reflect conditions of 2013. In this study, instead of relying on the remote-sensing-derived data or 
Table 1. EPA emission trends for $\mathrm{NO}_{\mathrm{x}}$ (values reported in thousands of tonnes.

\begin{tabular}{lrrrrrr}
\hline $\mathrm{NO}_{\mathrm{x}}$ & 2008 & 2009 & 2010 & 2011 & 2012 & 2013 \\
\hline Mobile & 6941 & 6241 & 5734 & 5786 & 5398 & 5,010 \\
Other & 9872 & 9540 & 9144 & 8594 & 8114 & 7914 \\
Total & 16813 & 15781 & 14878 & 14380 & 13512 & 12924 \\
\hline
\end{tabular}

surface-measured data to adjust an emission inventory (e.g., Kim et al., 2009; Kim et al., 2011; Choi et al., 2012; Choi, 2014) we use the long-term trends of anthropogenic $\mathrm{NO}_{\mathrm{x}}$ emission reported by U.S. EPA. Then the impact of the adjusted $\mathrm{NO}_{\mathrm{x}}$ emissions on surface $\mathrm{NO}_{\mathrm{x}}$ concentrations is evaluated by comparing the simulated and observed $\mathrm{NO}_{\mathrm{x}}$ concentrations. According to EPA, emissions of nitrogen oxides from anthropogenic sources were reduced between 2008 and 2013. Table 1 shows emission values based on the EPA trends (available at http://www.epa.gov/ttn/chief/trends/index.html) for on-road mobile sources and other anthropogenic sources excluding wildfires. Relatively to values for the year 2008 there was $28 \%$ reduction in on-road mobile $\mathrm{NO}_{\mathrm{x}}$ emissions on a nationwide scale and $20 \%$ reduction in other anthropogenic $\mathrm{NO}_{\mathrm{x}}$ emissions in year 2013. To follow the emissions trends we created a sensitivity case in which on-road $\mathrm{NO}_{\mathrm{x}}$ emissions were reduced by $30 \%$ and anthropogenic point source emissions were reduced by $20 \%$.

NEI provides emission rates for nitrogen oxides; during the processing with $\mathrm{SMOKE} \mathrm{NO}_{\mathrm{x}}$ emissions for mobile sources are separated into $90 \% \mathrm{NO}, 9.2 \% \mathrm{NO}_{2}$, and $0.8 \%$ HONO. However, Rappenglueck et al. (2013) report much higher HONO contribution from mobile sources in Houston; based on all measurements HONO traffic emissions are $1.7 \%$ of $\mathrm{NO}_{\mathrm{x}}$ emissions, which is about twice the previously estimated value of $0.8 \%$ based on tunnel measurements in 2001. The HONO / $\mathrm{NO}_{\mathrm{x}}$ ratio reported by Kurtenbach et al. (2001) is based on measurements performed between 6 a.m. and 2 p.m., for both weekdays and weekends where $22200 \pm 400$ vehicles were passing on weekdays and $13300 \pm 1400$ cars passing on weekends. The vehicle fleet was composed of $6.0 \%$ heavy-duty trucks, $6.0 \%$ commercial vans, $12 \%$ diesel and $75 \%$ gasoline powered passenger cars, and $1.0 \%$ motorcycles. The ratio calculated by Rappenglueck et al. (2013) is based on measurements performed during weekdays reflecting high-traffic, early morning conditions (4-8 a.m.). The measurements were performed at highway junction in Houston with very high traffic load (about 400000 vehicles passing daily), which is much larger than that in the tunnel study. The vehicle fleet was represented by 93-95\% of gasoline fueled vehicles and $5-7 \%$ by diesels during the morning hours. Another difference between these two studies is in vehicle speed, with a typical speed of 50$90 \mathrm{~km}^{-1}$ in the tunnel studies and much lower speed during the morning peak traffic hours in Houston. To reflect the latest values of HONO emissions measured in Houston in air

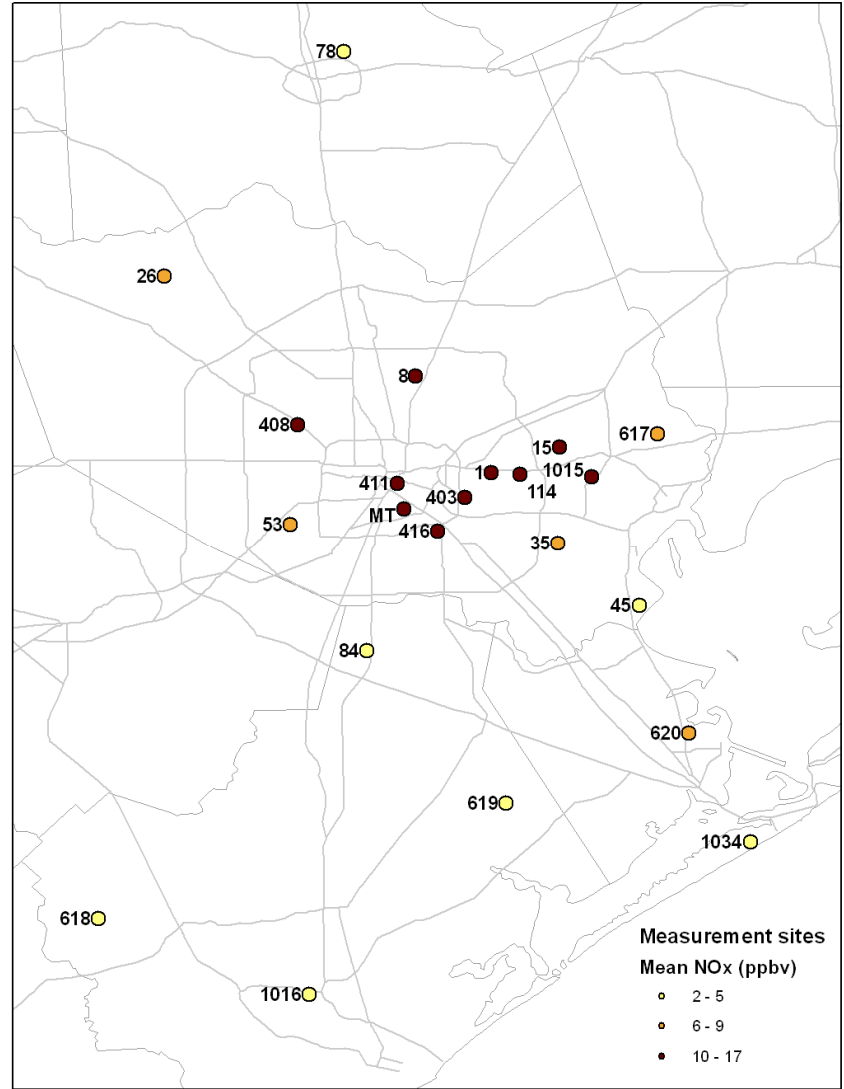

Figure 1. Locations of stations performing $\mathrm{NO}_{\mathrm{x}}$ measurements in the Houston-Galveston-Brazoria area during September 2013.

quality modeling, an additional sensitivity case was created in which contribution of HONO from mobile sources was doubled at the cost of $\mathrm{NO}_{2}$. The following speciation was used for the sensitivity case: $90 \% \mathrm{NO}, 8.4 \% \mathrm{NO}_{2}$, and $1.6 \%$ HONO. It is worth noting that, since the newly reported ratio reflects high-traffic conditions during morning rush hours on weekdays, our model sensitivity study provides an estimate of the upper bound of the impact of HONO emissions on pollutant levels in urban areas.

The following three simulations cases are performed and analyzed in this study: (i) $\mathrm{B}$ - base case, with $\mathrm{NO}_{\mathrm{x}}$ emissions rates obtained from NEI2008 and $\mathrm{HONO} / \mathrm{NO}_{\mathrm{x}}=0.008$; (ii) $\mathrm{N}$ - reduced emissions of $\mathrm{NO}_{\mathrm{x}}$ case: mobile sources $\times 0.7$, point sources $\times 0.8$; $\mathrm{HONO} / \mathrm{NO}_{\mathrm{x}}=0.008$; and (iii) $\mathrm{NH}-$ similar to $\mathrm{N}$ but with doubled $\mathrm{HONO}$ emissions from mobile sources (this is $\mathrm{HONO} / \mathrm{NO}_{\mathrm{x}}=0.016$ ).

\subsection{Measurements}

Measured values from the Continuous Ambient Monitoring Stations (CAMS) system, operated by the Texas Commission on Environmental Quality (TCEQ), were utilized for evaluating $\mathrm{NO}_{\mathrm{x}}$ emission inventory. During the time period of interest 30 stations inside our $4 \mathrm{~km}$ modeling domain re- 
Table 2. Summary of statistical parameters for the base case simulation (B) and reduced $\mathrm{NO}_{\mathrm{x}}$ case $(\mathrm{N})$.

\begin{tabular}{|c|c|c|c|c|c|c|c|c|c|c|}
\hline \multirow[t]{2}{*}{ Site } & \multirow[t]{2}{*}{ No. of points } & \multicolumn{3}{|c|}{ Mean (ppb) } & \multicolumn{2}{|c|}{$R$} & \multicolumn{2}{|c|}{ AME (ppb) } & \multicolumn{2}{|c|}{ IOA } \\
\hline & & Obs. & Sim. B & Sim. N & Sim. B & Sim. N & Sim. B & Sim. N & Sim. B & Sim. N \\
\hline 1 & 700 & 15.60 & 18.95 & 12.41 & 0.44 & 0.45 & 10.52 & 8.18 & 0.62 & 0.58 \\
\hline 2 & 695 & 6.34 & 9.13 & 5.42 & 0.49 & 0.54 & 5.39 & 3.62 & 0.54 & 0.70 \\
\hline 8 & 699 & 9.93 & 11.89 & 8.24 & 0.73 & 0.76 & 5.45 & 4.53 & 0.83 & 0.84 \\
\hline 9 & 699 & 5.50 & 10.02 & 6.54 & 0.60 & 0.59 & 5.66 & 3.74 & 0.66 & 0.74 \\
\hline 15 & 668 & 10.48 & 12.98 & 7.92 & 0.42 & 0.44 & 8.20 & 6.26 & 0.61 & 0.56 \\
\hline 26 & 697 & 5.61 & 12.58 & 9.58 & 0.52 & 0.56 & 7.96 & 5.45 & 0.47 & 0.61 \\
\hline 35 & 649 & 6.63 & 10.33 & 6.95 & 0.67 & 0.64 & 5.87 & 3.93 & 0.72 & 0.79 \\
\hline 45 & 699 & 3.83 & 4.87 & 3.45 & 0.60 & 0.52 & 2.94 & 2.42 & 0.72 & 0.70 \\
\hline 53 & 684 & 7.69 & 11.56 & 8.80 & 0.76 & 0.77 & 5.74 & 4.28 & 0.82 & 0.87 \\
\hline 64 & 690 & 4.01 & 2.51 & 1.91 & 0.44 & 0.54 & 2.72 & 2.57 & 0.61 & 0.57 \\
\hline 78 & 617 & 3.29 & 10.45 & 7.56 & 0.54 & 0.55 & 7.66 & 5.01 & 0.41 & 0.54 \\
\hline 84 & 533 & 4.34 & 9.08 & 6.88 & 0.69 & 0.70 & 5.57 & 3.82 & 0.68 & 0.78 \\
\hline 114 & 708 & 13.94 & 20.87 & 13.79 & 0.48 & 0.50 & 11.44 & 7.54 & 0.62 & 0.68 \\
\hline 311 & 635 & 4.58 & 6.75 & 4.92 & 0.52 & 0.58 & 3.74 & 2.70 & 0.66 & 0.75 \\
\hline 403 & 696 & 14.87 & 27.20 & 20.08 & 0.40 & 0.42 & 16.40 & 11.83 & 0.54 & 0.61 \\
\hline 408 & 703 & 15.17 & 12.01 & 8.90 & 0.55 & 0.59 & 7.08 & 7.74 & 0.67 & 0.61 \\
\hline 411 & 692 & 16.57 & 22.24 & 15.81 & 0.59 & 0.60 & 10.59 & 7.87 & 0.69 & 0.76 \\
\hline 416 & 702 & 13.95 & 28.35 & 19.43 & 0.71 & 0.71 & 16.39 & 9.29 & 0.69 & 0.81 \\
\hline 617 & 705 & 6.20 & 7.42 & 4.93 & 0.50 & 0.48 & 4.50 & 3.61 & 0.64 & 0.68 \\
\hline 618 & 697 & 2.90 & 3.15 & 1.80 & 0.58 & 0.61 & 1.62 & 1.42 & 0.71 & 0.71 \\
\hline 619 & 559 & 3.04 & 2.38 & 1.67 & 0.38 & 0.48 & 2.34 & 2.01 & 0.58 & 0.58 \\
\hline 620 & 399 & 7.05 & 7.66 & 4.86 & 0.37 & 0.36 & 6.74 & 5.67 & 0.57 & 0.49 \\
\hline 640 & 675 & 2.14 & 1.57 & 1.10 & 0.26 & 0.30 & 1.50 & 1.36 & 0.47 & 0.47 \\
\hline 643 & 671 & 6.30 & 1.82 & 1.35 & 0.21 & 0.24 & 4.97 & 5.15 & 0.46 & 0.44 \\
\hline 1015 & 703 & 13.44 & 12.33 & 8.75 & 0.43 & 0.44 & 8.95 & 8.65 & 0.62 & 0.56 \\
\hline 1016 & 608 & 2.25 & 5.18 & 3.73 & 0.40 & 0.40 & 3.55 & 2.50 & 0.48 & 0.57 \\
\hline 1034 & 641 & 2.23 & 1.58 & 1.38 & 0.45 & 0.47 & 1.43 & 1.39 & 0.63 & 0.60 \\
\hline 1035 & 692 & 4.45 & 7.91 & 5.12 & 0.53 & 0.55 & 4.49 & 2.96 & 0.64 & 0.74 \\
\hline 1628 & 630 & 5.91 & 13.64 & 5.09 & 0.43 & 0.50 & 8.39 & 2.98 & 0.42 & 0.69 \\
\hline MT & 703 & 9.93 & 20.53 & 14.59 & 0.64 & 0.64 & 12.46 & 8.02 & 0.63 & 0.74 \\
\hline ALL & 19849 & 7.76 & 11.11 & 7.59 & 0.58 & 0.59 & 6.76 & 4.94 & 0.71 & 0.75 \\
\hline
\end{tabular}

ported $\mathrm{NO}_{\mathrm{x}}$ measurements. Figure 1 shows locations of sites in the Houston-Galveston metropolitan area, where color of the symbol indicates the measured mean $\mathrm{NO}_{\mathrm{x}}$ mixing ratios during the month of September 2013. Several sites, such as $78,84,618,619$, and 1016, have low mean values; those sites reflect regional and/or suburban conditions. A couple of sites, such as 26 and 53, have medium-range $\mathrm{NO}_{\mathrm{x}}$ values reflecting urban air mixture dominated by traffic emissions. Many sites close to highways or in downtown Houston and east of downtown are exposed to heavy traffic as well as a combination of traffic and industrial emissions. They have very high $\mathrm{NO}_{\mathrm{x}}$ mean values; those are CAMS sites 1, 8, 114, 403, 408, 411 and the Moody Tower (MT) site described below.

The Moody Tower, located east of downtown, was designated as a "super" site during air quality study campaigns in Houston in years 2006 (Lefer and Rappenglück, 2010) and 2009 (Olaguer et al., 2013) during which many chemical and meteorological measurements were taken. During September 2013 measurements at the Moody Tower complemented the DISCOVER-AQ campaign. The measurements were taken at
$60 \mathrm{~m}$ a.g.l. In addition to $\mathrm{NO}_{\mathrm{x}}$ and ozone, $\mathrm{HONO}$ was also measured on several days during the month of September 2013.

\section{Results}

\subsection{Evaluation of $\mathrm{NO}_{\mathrm{x}}$ modeling}

Table 2 shows summary of statistical parameters of modeled $\mathrm{NO}_{\mathrm{x}}$ mixing ratios for the base case (B) and the reduced $\mathrm{NO}_{\mathrm{x}}$ case $(\mathrm{N})$ as compared to measured values at CAMS sites, where $R$ is the Pearson coefficient, and AME is the absolute mean error calculated as

$\mathrm{AME}=\left(\frac{1}{n}\right) \sum_{1}^{n}\left|C_{\mathrm{m}}-C_{\mathrm{o}}\right|$,

where $n$ is the number of data points, " $m$ " corresponds to modeled mixing ratios and "o" to observed ones; IOA is the index of agreement, calculated according the following equa- 

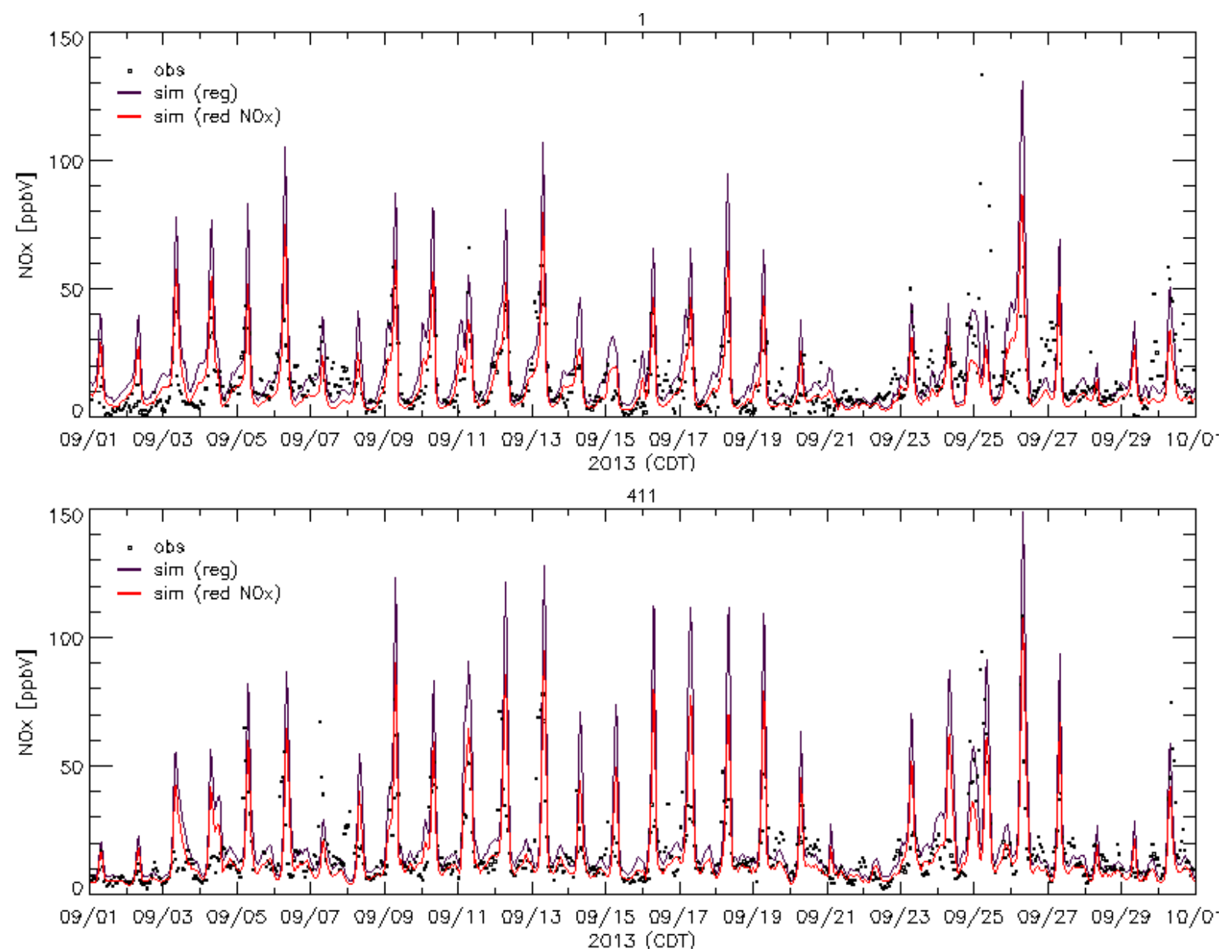

Figure 2. Time series comparing measured $\mathrm{NO}_{\mathrm{x}}$ against values simulated with the base case and the reduced $\mathrm{NO}_{\mathrm{x}}$ case at $\mathrm{CAMS}$ sites 1 (top) and 411 (bottom).

tion:

$\mathrm{IOA}=1-\frac{\sum_{1}^{n}\left(C_{\mathrm{m}}-C_{\mathrm{o}}\right)^{2}}{\sum_{1}^{n}\left(\left|C_{\mathrm{o}}-\widetilde{O}\right|+\left|C_{\mathrm{m}}-\widetilde{O}\right|\right)^{2}}$,

where $\widetilde{O}$ corresponds to the observed mean value. Compared to a Pearson coefficient the index of agreement is a more comprehensive measure of how well the concentrations are predicted since it takes into account not only scattering of data but also biases (Willmott, 1981).

Statistical parameters were calculated for all available data pairs from CAMS sites inside the modeling domain. The measured mean value from all sites is $7.76 \mathrm{ppbv}$; the simulated mean value dropped from $11.11 \mathrm{ppbv}$ in the base case to $7.59 \mathrm{ppbv}$ in the reduced $\mathrm{NO}_{\mathrm{x}}$ case becoming closer to the observed mean. Both $R$ and IOA are improved in the reduced $\mathrm{NO}_{\mathrm{x}}$ case $(R=0.58, \mathrm{IOA}=0.71$ in the base case; $R=0.59$, $\mathrm{IOA}=0.75$ in the reduced $\mathrm{NO}_{\mathrm{x}}$ case) and AME is lowered from 6.76 to 4.94 ppbv. Overall, the reduced $\mathrm{NO}_{\mathrm{x}}$ simulation case gives better $\mathrm{NO}_{\mathrm{x}}$ prediction in comparison to the base case. When looking at individual stations affected by emissions from different sources the improvement from $\mathrm{NO}_{\mathrm{x}}$ reductions is beneficial for most of sites, but leads to underpredictions at several sites. Many stations with medium-range $\mathrm{NO}_{\mathrm{x}}$ mixing ratios, such as CAMS 35 and 53, show improvement from $\mathrm{NO}_{\mathrm{x}}$ reduction. There are also cases when $\mathrm{NO}_{\mathrm{x}}$ continues to be too high even after reduction of emissions. This is the case for CAMS sites 26 and 78 that represent suburban conditions with low measured $\mathrm{NO}_{\mathrm{x}}$ mixing ratios (usually below $10 \mathrm{ppb}$ ) and low mean values of 5.61 and 3.29 , respectively. The model represents them as urban sites with significant traffic signature and therefore with much higher than measured mixing ratios. Even though in our study we adjusted $\mathrm{NO}_{\mathrm{x}}$ emissions to reflect emission reduction between the year 2008 and 2013 some overpredictions may occur since, as pointed by Choi (2014), $\mathrm{NO}_{\mathrm{x}}$ rates in the base 2008 inventory might be too high. Very high $\mathrm{NO}_{\mathrm{x}}$ mixing ratios are recorded in areas with heavy traffic and close to industrial facilities in the eastern part of Houston - such as at 

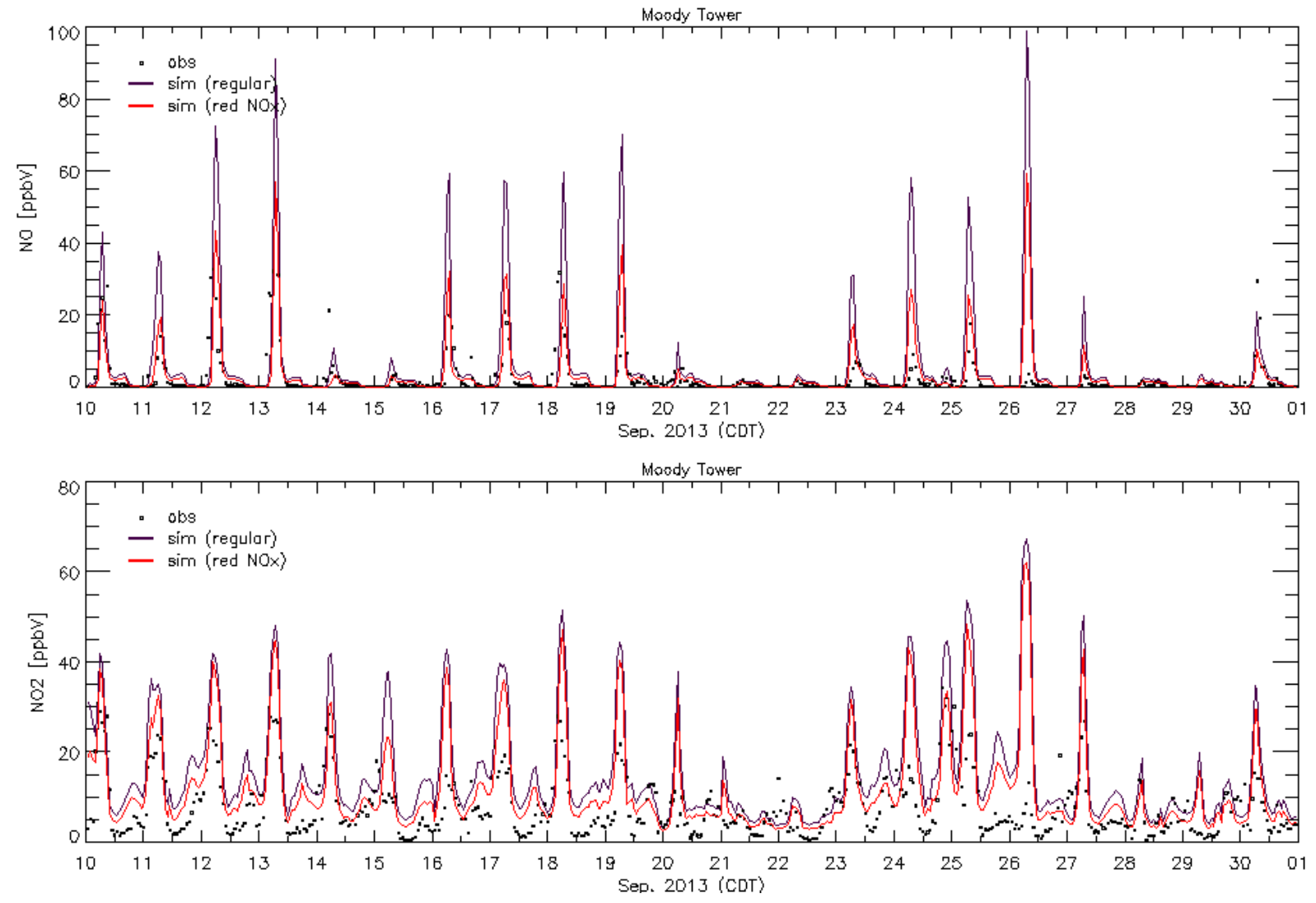

Figure 3. $\mathrm{NO}$ and $\mathrm{NO}_{2}$ mixing ratio measured at the Moody Tower site and modeled with the base case emissions as well as with reduced $\mathrm{NO}_{\mathrm{X}}$ emissions.

\section{Difference in HONO emissions (NH-N)}
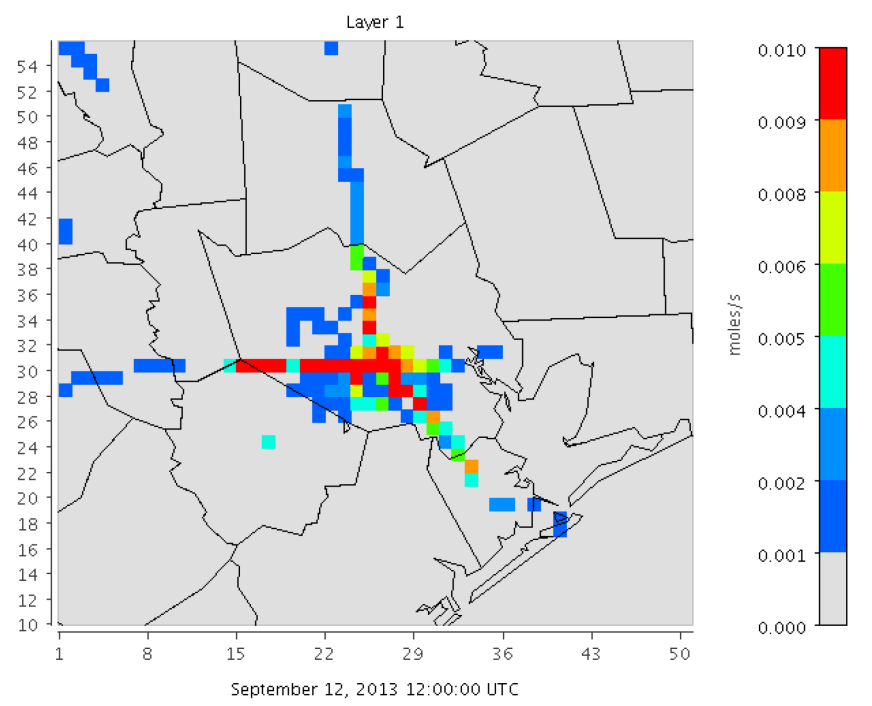

Figure 4. Snapshot of differences in HONO emissions between a case with emission ratio of $\mathrm{HONO} / \mathrm{NO}_{\mathrm{x}}=0.016(\mathrm{NH})$ and default emissions of $\mathrm{HONO} / \mathrm{NO}_{\mathrm{x}}=0.008(\mathrm{~N})$ at 7 a.m. LT on 12 September 2013 .
CAMS stations $1,403,411$, and $416 . \mathrm{NO}_{\mathrm{x}}$ mixing ratios at those stations were heavily overpredicted and consequently those stations benefit the most from $\mathrm{NO}_{\mathrm{x}}$ reductions as presented in Fig. 2. Our results are similar to the previous study by Choi (2014), who issued that $\mathrm{NO}_{\mathrm{x}}$ mixing ratios at urban regions are overpredicted by air quality models, but $\mathrm{NO}_{\mathrm{x}}$ at the rural regions is underpredicted.

The Moody Tower site served as a super site for a couple of measurement campaigns in Houston, and many different chemical and meteorological parameters were measured there, including $\mathrm{NO}, \mathrm{NO}_{2}$, and HONO. It is located in close proximity to downtown and major highways and is affected by quite high $\mathrm{NO}_{\mathrm{x}}$ emissions. Figure 3 shows comparison of measured at the Moody Tower and simulated mixing ratios of $\mathrm{NO}$ (top) and $\mathrm{NO}_{2}$ (bottom). Again, two simulation cases are compared: the case with regular emissions as included in NEI2008 (B) and the reduced $\mathrm{NO}_{\mathrm{x}}$ emissions case (N). It can be seen that for both compounds the peak values were overpredicted by the base case while reduced $\mathrm{NO}_{\mathrm{x}}$ case resulted in lower mixing ratios making them closer to the observed values. In particular, NO mixing ratios are much better predicted by the reduced $\mathrm{NO}_{\mathrm{x}}$ emission case. Both $\mathrm{NO}_{2}$ morning peaks and low-range daytime and nighttime $\mathrm{NO}_{2}$ values, 

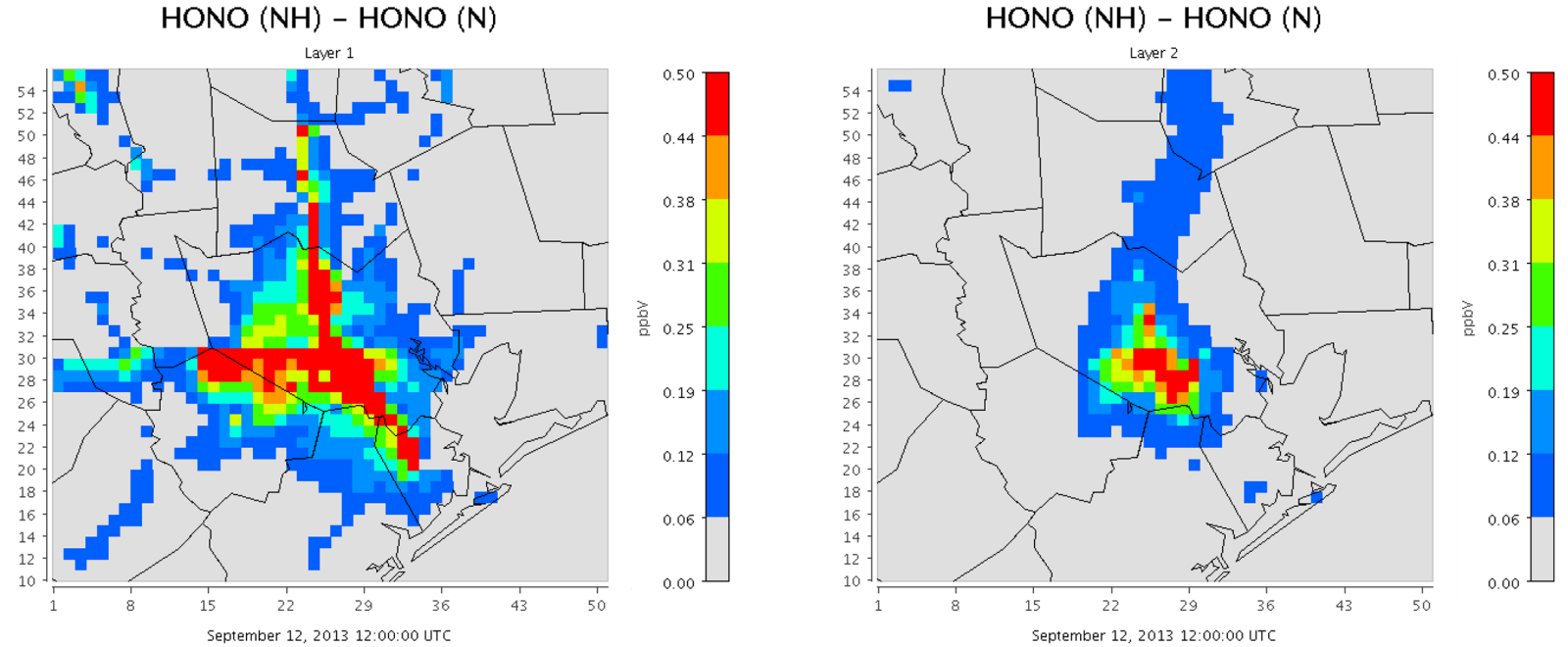

Figure 5. Differences in $\mathrm{HONO}$ mixing ratios between a case with $0.016 \mathrm{HONO} / \mathrm{NO}_{\mathrm{x}}$ emission ratio $(\mathrm{NH})$ and $0.008 \mathrm{HONO} / \mathrm{NO}$ emissions (N) for the surface (left) and the second model layer (right) at 7 a.m. LT on 12 September 2013.

although lowered, continue to be overpredicted most of the time.

\subsection{HONO modeling}

Since reduction of $\mathrm{NO}_{\mathrm{x}}$ emissions resulted in better prediction of $\mathrm{NO}_{\mathrm{x}}$ mixing ratios at the Moody Tower and nearby areas, this case was used as a base for modifying HONO emissions. Figure 4 shows changes in $\mathrm{HONO}$ emissions rates between the sensitivity case in which $\mathrm{HONO} / \mathrm{NO}_{\mathrm{x}}=0.016$ (indicated as $\mathrm{NH}$ ) and the reduced $\mathrm{NO}_{\mathrm{x}}$ case that used $\mathrm{HONO} / \mathrm{NO}_{\mathrm{x}}=0.008$ (indicated as $\mathrm{N}$ ). Doubling HONO emissions resulted in up to 0.01 mole $^{-1}$ increase in emission rates from mobile sources along highways. Figure 5 shows differences in simulated mixing ratios of HONO for morning conditions at 7 a.m. LT that correspond to the time of the highest HONO emissions from traffic and the highest HONO mixing ratios. The left panel shows results for the surface layer. It can be seen that changes in HONO mixing ratio at the surface occur along highways following the pattern of emission changes presented in Fig. 4. Differences in HONO mixing ratios at the second modeled layer, which corresponds to measurements taken at the Moody Tower, are shown in the right panel of Fig. 5. At this level the air is mixed and the spatial signature of mobile emissions diminishes.

HONO is not routinely measured in Houston; in spite of that, during September 2013 HONO was measured at the Moody Tower to complement measurements during DISCOVER-AQ campaign. However, the measurements were not continuous and the data are limited to several days. Figure 6 shows time series of measured and simulated HONO mixing ratios at the Moody Tower. The mixing ratios obtained from the reduced $\mathrm{NO}_{\mathrm{x}}$ simulation case $(\mathrm{N})$, for
Table 3. Statistical parameters for modeling HONO mixing ratios for the Moody Tower site.

\begin{tabular}{llr}
\hline Statistics & & HONO \\
\hline Number of points & & 200 \\
\hline Mean & Observed & 0.69 \\
& Sim. (N) & 0.30 \\
& Sim. (NH) & 0.41 \\
\hline Max. value & Observed & 3.15 \\
& Sim. (N) & 2.62 \\
& Sim. (NH) & 2.93 \\
\hline Correlation coefficient & Sim. (N) & 0.58 \\
& Sim. (NH) & 0.57 \\
\hline Mean bias & Sim. (N) & -0.39 \\
& Sim. (NH) & -0.28 \\
\hline Absolute mean error & Sim. (N) & 0.46 \\
& Sim. (NH) & 0.43 \\
\hline Index of agreement & Sim. (N) & 0.63 \\
& Sim. (NH) & 0.70 \\
\hline
\end{tabular}

which the $\mathrm{HONO} / \mathrm{NO}_{\mathrm{x}}$ emission ratio of 0.008 was used, are much lower than observed HONO values. The values from the increased HONO case $(\mathrm{NH})$, with the $\mathrm{HONO} / \mathrm{NO}_{x}$ emission ratio of 0.016 , are higher, especially the morning peaks, and closer to the observations. The statistical parameters for HONO modeling at the Moody Tower are presented in Table 3. The mean value increased from 0.30 in the base case to $0.41 \mathrm{ppbv}$ in the increased HONO emissions case but continue to be lower than the observed mean of $0.69 \mathrm{ppbv}$. The index of agreement increased from 0.63 to 0.70 indicating benefits of increased HONO emissions. Clearly, im- 


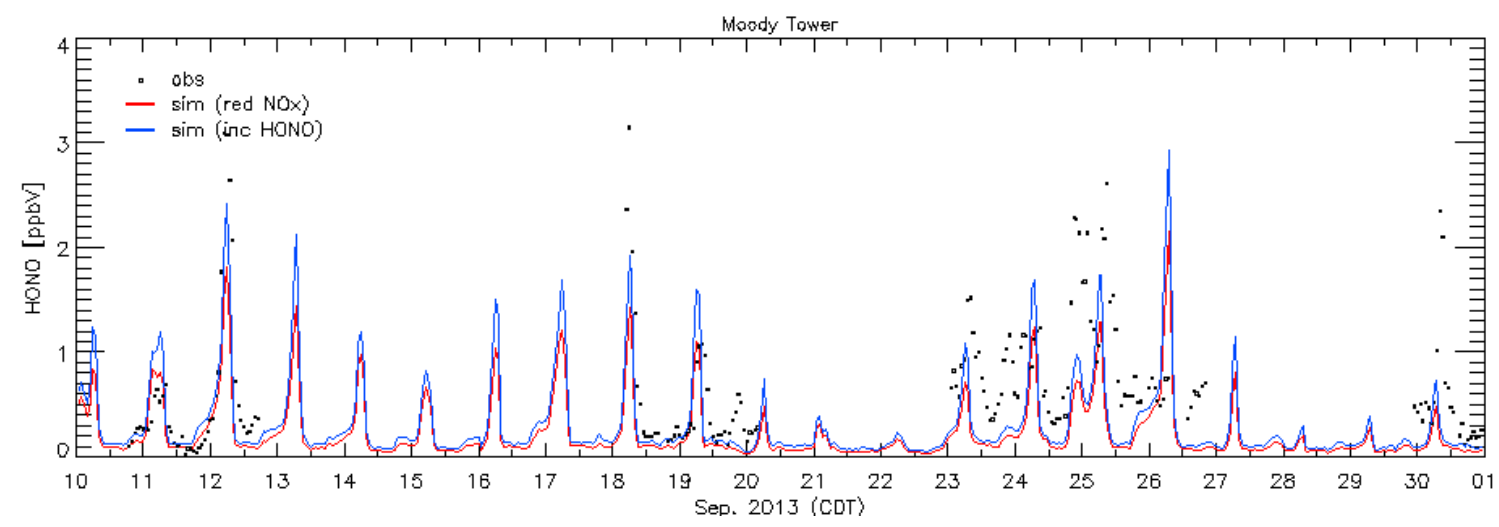

Figure 6. HONO mixing ratios measured at the Moody Tower site and modeled with and the regular HONO emissions (N) for which the $\mathrm{HONO} / \mathrm{NO}_{\mathrm{x}}$ emission ratio of 0.008 was used, and the increased $\mathrm{HONO}$ case $(\mathrm{NH})$ for which the $\mathrm{HONO} / \mathrm{NO}_{\mathrm{x}}$ emission ratio of 0.016 was used.

provement in HONO peak values can be seen on 12, 18, 23, 24, 25 and 30 September; especially on 12 September the model with increased HONO emissions nicely follows $\mathrm{HONO}$ peak while the case with low $\mathrm{HONO} / \mathrm{NO}_{\mathrm{x}}$ emission rates resulted in underprediction of the peak value. However, as pointed by Czader et al. (2012) HONO predictions depend on how well the model captures $\mathrm{NO}_{\mathrm{x}}$ concentrations, especially $\mathrm{NO}_{2}$, since heterogeneous $\mathrm{HONO}$ formation is directly related to $\mathrm{NO}_{2}$ concentrations and greatly influences morning HONO mixing ratios. It can be seen that overprediction of $\mathrm{NO}$ and $\mathrm{NO}_{2}$ on 11, 19, and 24 September leads to overprediction of HONO. We can conclude that to a large extent misprediction of precursors is responsible for HONO misprediction and expect that if $\mathrm{NO}_{\mathrm{x}}$ mixing ratios for those days are accurately simulated also $\mathrm{HONO}$ values would be closer to observation. This is not the case on 18 September when, despite the fact that $\mathrm{NO}$ is well predicted and $\mathrm{NO}_{2}$ overpredicted, HONO peak is underpredicted. The reasoning for that is unknown, but it is probably due to the uncertainties in other HONO sources. Also, variations of simulated HONO mixing ratios from day to day are influenced not only by emissions but also by other parameters, for example, the model capabilities to predict growth of the mixing layer and wind fields as well as clouds that influence photolysis rates. To more clearly present differences between the two simulated cases $(\mathrm{N}$ and $\mathrm{NH}$ ) and measured data we calculated the average diurnal profiles of HONO and presented them in Figure 7. The modeled profiles follow the measured one showing a high peak in the morning and low values during a daytime. It can be seen that the NH scenario, in which higher emission ratio was utilized, improves HONO morning peaks. Since only HONO emissions from mobile sources were increased, it is expected to see the largest differences in mixing ratios during early morning times when the traffic emissions are high, the mixing layer height low allowing for accumulation of HONO, and photochemistry not very active. It is worth noting that all available measured data for HONO for September 2013

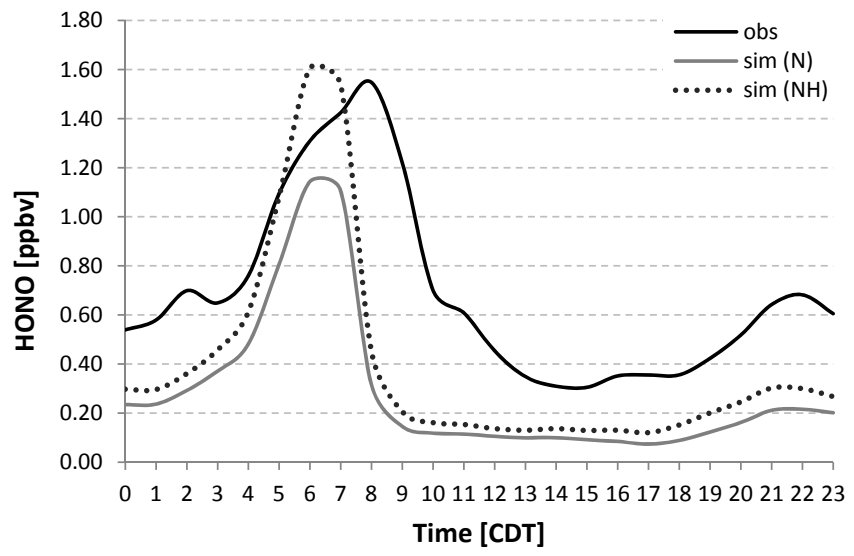

Figure 7. Average diurnal variation of $\mathrm{HONO}$ at the Moody Tower measurement site.

are from weekdays and the higher $\mathrm{HONO} / \mathrm{NO}_{\mathrm{x}}$ ratio measured in Houston was also calculated based on measurements taken during weekdays. The model underprediction during daytime can be explained by the fact that the default model version that we used in this study does not account for the photochemical HONO sources. Also, too low modeled average profile during daytime is caused by underpredictions of HONO on 23-25 September which can be attributed to stronger modeled winds in comparison to weak observed winds causing modeled HONO to be removed from the observational site.

The photolysis of HONO is a source of hydroxyl radical. Figure 8 shows a snapshot of spatial pattern of $\mathrm{OH}$ mixing ratios (left) and differences in $\mathrm{OH}$ mixing ratios (right) between simulations with increased HONO emissions (NH) and regular emissions with $0.008 \mathrm{HONO} / \mathrm{NO}_{\mathrm{x}}$ emissions ratio $(\mathrm{N})$ for 12 September, which is a day with nicely predicted HONO mixing ratios. An increase in $\mathrm{OH}$ occurs along highways corresponding to increased HONO mobile emissions. 

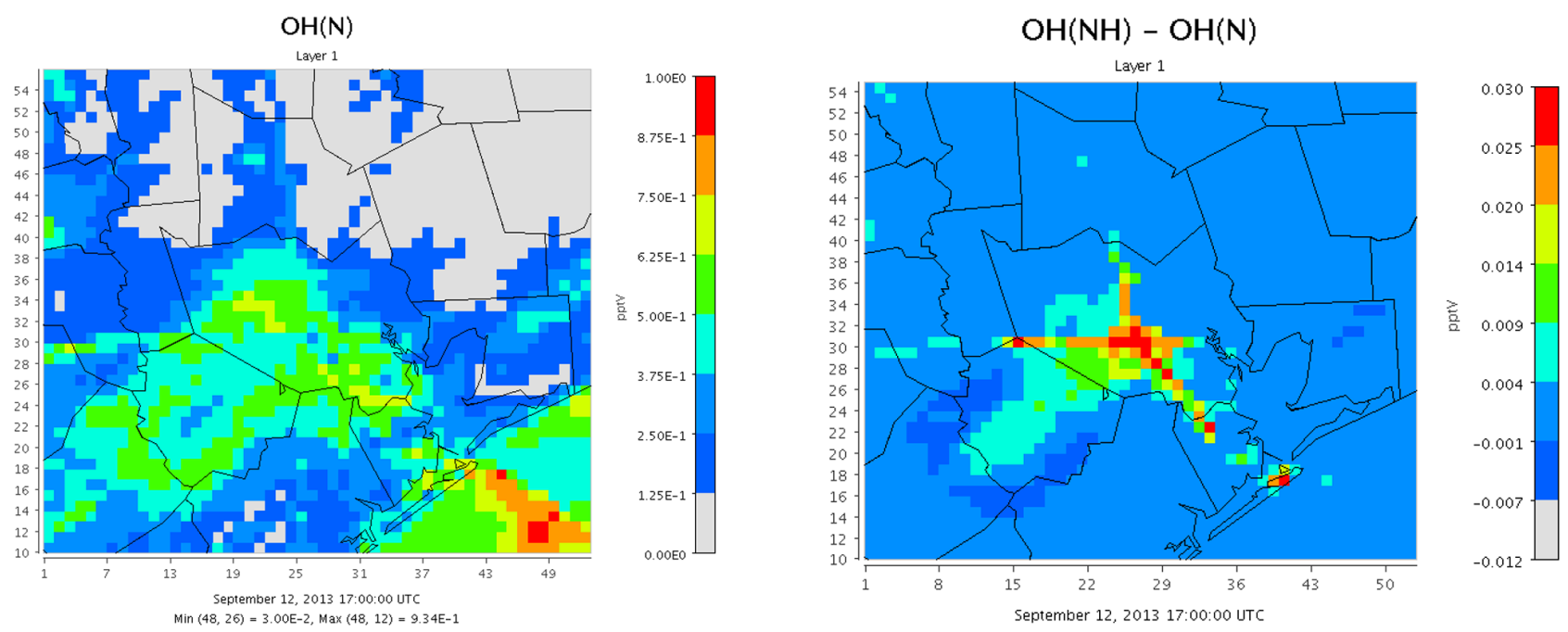

Figure 8. $\mathrm{OH}$ mixing ratios (left) and differences in $\mathrm{OH}$ mixing ratios (right) between the case with $0.008 \mathrm{HONO} / \mathrm{NO}_{\mathrm{x}}$ emission ratio $(\mathrm{N})$ and $0.016 \mathrm{HONO} / \mathrm{NO}_{\mathrm{x}}$ emission ratio $(\mathrm{NH})$ at noon local time on 12 September 2013.

Based on the 1 month of simulated surface concentrations the average increase in HONO due to doubling its emissions from mobile sources is $36 \%$ at the location of the Moody Tower and $10 \%$ when averaged over the urban area. The average increase in the morning $\mathrm{OH}$ (between 6 and 8 a.m. LT) is $14 \%$ at the location of the Moody Tower and $3 \%$ when averaged over the urban area. The ozone increase is below $1 \%$ for both the Moody Tower and the urban area. The average increase in $\mathrm{OH}$ during daytime ( 6 a.m.- -8 p.m. LT) is $7 \%$ for the Moody Tower and $1 \%$ for the urban area. The increase in ozone is again below $1 \%$. Since HONO emissions from mobile sources that peak in the morning were modified, it is therefore understandable that the impact of these additional $\mathrm{HONO}$ emissions on $\mathrm{OH}$ and ozone is higher during morning time than afternoon hours.

To obtain more insights on the fate of HONO we performed additional model simulations in which we utilized the process analysis that provides information on chemical and physical processes influencing pollutant mixing ratios. The analysis was performed for the Moody Tower site for 10-13 September 2013. At the surface, at the location of the Moody Tower the average contribution of vertical transport to the loss of HONO is $77 \%$; horizontal transport contributes $8 \%$, chemical removal $11 \%$ and dry deposition $4 \%$. HONO mixing ratios along with process affecting changes in mixing ratios for the second model layer, which corresponds to the altitude of measurements, are presented in Fig. 9. It can be seen that transport (horizontal and vertical) continues to be a dominant loss process at this altitude contributing on average $77 \%$ to the total HONO loss while chemical loss contributes only $23 \%$ to the total loss. The chemical loss of HONO is dominant only during a couple of morning hours. This explains the fact that, even though HONO mixing ratios significantly increased upon additional emissions, HONO was

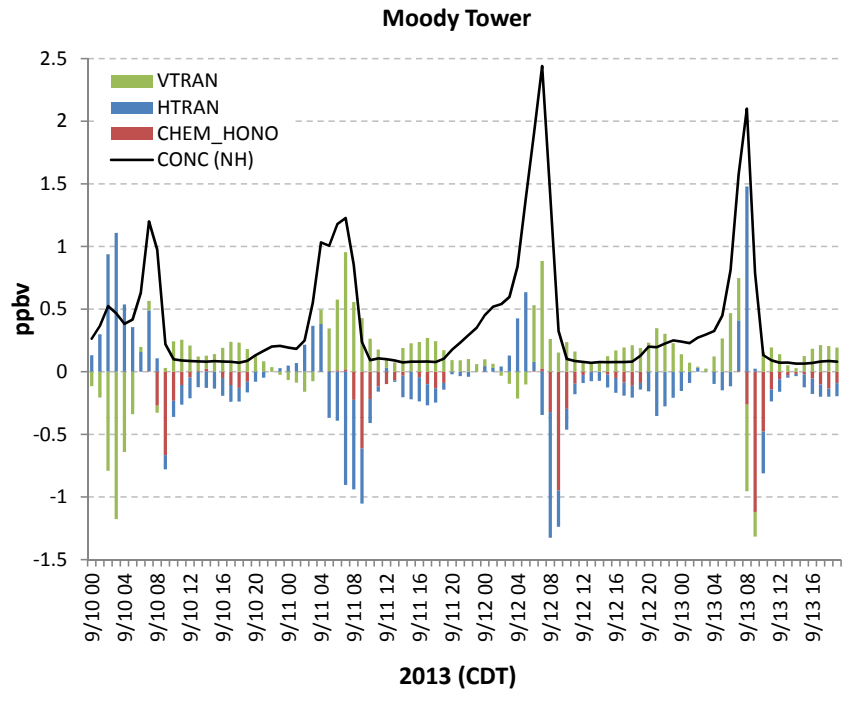

Figure 9. HONO mixing ratios (black line) and processes contributing to changes in HONO mixing ratio at the Moody Tower site where the measurements were taken, which corresponds to the second model layer, where VTRAN is vertical transport, HTRAN is transport in horizontal direction, and CHEM_HONO corresponds to changes due to chemical reactions.

removed mainly by transport with only small portions taking part in chemical reactions converting it to $\mathrm{OH}$ and furthermore to $\mathrm{O}_{3}$.

\section{Summary}

The WRF-SMOKE-CMAQ modeling system was used for evaluation and adjustment of $\mathrm{NO}_{\mathrm{x}}$ emissions. In particular, $\mathrm{HONO} / \mathrm{NO}_{\mathrm{x}}$ emission ratio from mobile sources was in- 
creased and its impact on HONO mixing ratios as well as on $\mathrm{OH}$ and $\mathrm{O}_{3}$ was evaluated.

First, $\mathrm{NO}_{\mathrm{x}}$ emissions were adjusted to reflect emission trends. Simulations with adjusted $\mathrm{NO}_{\mathrm{x}}$ emissions resulted in overall better $\mathrm{NO}_{\mathrm{x}}$ prediction as mixing ratios became closer to measured values. The average $\mathrm{NO}_{\mathrm{x}}$ mean value from all analyzed sites dropped from 11.11 to $7.59 \mathrm{ppbv}$ and is much closer to the observed mean of $7.76 \mathrm{ppbv}$. IOA is improved in the reduced $\mathrm{NO}_{\mathrm{x}}$ case $(0.71$ vs. 0.75$)$, and the AME is lowered from 6.76 to 4.94 . Therefore, the reduced $\mathrm{NO}_{\mathrm{x}}$ case was taken as a base for adjusting HONO emissions according to values measured in Houston.

Doubling HONO emission from mobile sources and therefore making them closer to the newly reported $\mathrm{HONO} / \mathrm{NO}_{\mathrm{x}}$ ratio of 0.017 resulted in increased HONO mixing ratios especially during morning peak values. Based on 1 month of simulated data, a $36 \%$ increase in HONO mixing ratio at the location of the Moody Tower was obtained from the case with higher emission ratios utilized in the simulation. The increase in HONO values averaged over the urban area was $10 \%$. Simulated HONO mixing ratios were compared to values measured at the Moody Tower. The mean value increased from $0.30 \mathrm{ppbv}$ in the base HONO emission case to $0.41 \mathrm{ppbv}$ in the increased HONO emission case and became closer to the observed mean of 0.69 , but still low. The index of agreement for simulation that used the $2001 \mathrm{HONO} / \mathrm{NO}_{\mathrm{x}}$ emission ratio of 0.008 is 0.63 while for the simulation with doubled HONO emissions IOA increased to 0.70. Increased HONO emissions from mobile sources resulted in a $14 \%$ increase in $\mathrm{OH}$ during morning time at the location of the Moody Tower and $3 \%$ when averaged over the urban area. The increase calculated for daytime was 7 and $1 \%$ for the Moody Tower and the urban area, respectively. The impact on ozone was found to be marginal (below $1 \%$ ).

This study results could shed light on the underestimated HONO in the morning from global/regional chemical transport model with the typical emission ratio of $0.8 \% \mathrm{HONO}$ emission out of the total $\mathrm{NO}_{\mathrm{x}}$ emissions. In addition, since HONO is the major radical source in the morning (e.g., Perner and Platt, 1979; Harris et al., 1982; Czader et al., 2013), underpredictions of HONO would lead to underprediction of $\mathrm{OH}$ radical.

Acknowledgements. The authors would like to thank the Texas Air Research Center (TARC) for supporting this work. They are also thankful to Lijun Diao for help in setting up WRF and to Hyuncheol Kim for helping with CAMS data set.

Edited by: B. N. Duncan

\section{References}

Amedro, D., Parker, A. E., Schoemaecker, C., and Fittschen, C.: Direct observation of $\mathrm{OH}$ radicals after $565 \mathrm{~nm}$ multi-photon ex- citation of $\mathrm{NO}_{2}$ in the presence of $\mathrm{H}_{2} \mathrm{O}$, Chem. Phys. Lett., 513, 12-16, doi:10.1016/j.cplett.2011.07.062, 2011.

Byun, D. and Schere, K. L.: Review of the Governing Equations, Computational Algorithms, and Other Components of the Models-3 Community Multiscale Air Quality (CMAQ) Modeling System, Appl. Mech. Rev., 59, 51-77, 2006.

Carr, S., Heard, D. E., and Blitz, M. A.: Comment on "Atmospheric Hydroxyl Radical Production from Electronically Excited $\mathrm{NO}_{2}$ and $\mathrm{H}_{2} \mathrm{O}$ ", Science, 324, p. 336, doi:10.1126/science.1166669, 2009.

Choi, Y.: The impact of satellite-adjusted $\mathrm{NO}_{\mathrm{x}}$ emissions on simulated $\mathrm{NO}_{\mathrm{x}}$ and $\mathrm{O}_{3}$ discrepancies in the urban and outflow areas of the Pacific and Lower Middle US, Atmos. Chem. Phys., 14, 675-690, doi:10.5194/acp-14-675-2014, 2014.

Choi, Y., Kim, H., Tong, D., and Lee, P.: Summertime weekly cycles of observed and modeled $\mathrm{NO}_{\mathrm{x}}$ and $\mathrm{O}_{3}$ concentrations as a function of satellite-derived ozone production sensitivity and land use types over the Continental United States, Atmos. Chem. Phys., 12, 6291-6307, doi:10.5194/acp-12-6291-2012, 2012.

Crowley, J. N. and Carl, S. A.: OH Formation in the Photoexcitation of $\mathrm{NO}_{2}$ beyond the Dissociation Threshold in the Presence of Water Vapor, J. Phys. Chem. A, 101, 4178-4184, 1997.

Czader, B. H., Rappenglück, B., Percell, P., Byun, D. W., Ngan, F., and Kim, S.: Modeling nitrous acid and its impact on ozone and hydroxyl radical during the Texas Air Quality Study 2006, Atmos. Chem. Phys., 12, 6939-6951, doi:10.5194/acp-12-69392012, 2012.

Czader, B. H., Li, X., and Rappenglueck, B.: CMAQ modeling and analysis of radicals, radical precursors and chemical transformations, J. Geophys. Res., 118, 11376-11387, doi:10.1002/jgrd.50807, 2013.

Elshorbany, Y. F., Kurtenbach, R., Wiesen, P., Lissi, E., Rubio, M., Villena, G., Gramsch, E., Rickard, A. R., Pilling, M. J., and Kleffmann, J.: Oxidation capacity of the city air of Santiago, Chile, Atmos. Chem. Phys., 9, 2257-2273, doi:10.5194/acp-92257-2009, 2009.

Finlayson-Pitts, B. J., Wingen, L. M., Sumner, A. L., Syomin, D., and Ramazan, K. A.: The heterogeneous hydrolysis of $\mathrm{NO}_{2}$ in laboratory systems and in outdoor and indoor atmospheres: and integrated mechanism, Phys. Chem. Chem. Phys., 5, 223-242, 2003.

Foley, K. M., Roselle, S. J., Appel, K. W., Bhave, P. V., Pleim, J. E., Otte, T. L., Mathur, R., Sarwar, G., Young, J. O., Gilliam, R. C., Nolte, C. G., Kelly, J. T., Gilliland, A. B., and Bash, J. O.: Incremental testing of the Community Multiscale Air Quality (CMAQ) modeling system version 4.7, Geosci. Model Dev., 3, 205-226, doi:10.5194/gmd-3-205-2010, 2010.

George, C., Sterkowski, R. S., Kleffmann, J., Stemmler, K., and Ammann, M.: Photoenhanced uptake of gaseous $\mathrm{NO}_{2}$ on solid organic compounds: a photochemical source of HONO?, Faraday Discuss., 130, 195-210, 2005.

Harris, G. W., Carter, W. P. L., Winer, A. M., Pitts, J. N., Platt, U., and Perner, D.: Observations of nitrous acid in the Los Angeles atmosphere and implications for the predictions of ozoneprecursor relationships, Environ. Sci. Technol., 16, 414-419, 1982.

Kim, S., VandenBoer, T. C., Young, C. J., Riedel, T. P., Thornton, J. A., Swarthout, B., Sive, B., Lerner, B., Gilman, J. B., Warneke, C., Roberts, J. M., Guenther, A., Wagner, N. L., Dubé, 
W. P., Williams, E., and Brown, S. S.: The Primary and Recycling Sources of OH During the NACHTT-2011 Campaign-HONO as an important $\mathrm{OH}$ primary source in the wintertime, J. Geophys. Res., 119, 6886-6896, doi:10.1002/2013JD019784, 2014.

Kim, S. W., Heckel, A., Frost, G. J., Richter, A., Gleason, J., Burrows, J. P., McKeen, S., Hsie, E.-Y., Granier, C., and Trainer, $\mathrm{M}: \mathrm{NO}_{2}$ columns in the western United States observed from space and simulated by a regional chemistry model and their implications for $\mathrm{NO}_{\mathrm{x}}$ emissions, J. Geophys. Res., 114, D11301, doi:10.1029/2008JD011343, 2009.

Kim, S.-W., McKeen, S. A., Frost, G. J., Lee, S.-H., Trainer, M., Richter, A., Angevine, W. M., Atlas, E., Bianco, L., Boersma, K. F., Brioude, J., Burrows, J. P., de Gouw, J., Fried, A., Gleason, J., Hilboll, A., Mellqvist, J., Peischl, J., Richter, D., Rivera, C., Ryerson, T., te Lintel Hekkert, S., Walega, J., Warneke, C., Weibring, P., and Williams, E.: Evaluations of NOx and highly reactive VOC emission inventories in Texas and their implications for ozone plume simulations during the Texas Air Quality Study 2006, Atmos. Chem. Phys., 11, 11361-11386, doi:10.5194/acp11-11361-2011, 2011.

Kirchstetter, T. W., Harley, R. A., and Littlejohn, D.: Measurement of nitrous acid in motor vehicle exhaust, Environ. Sci. Technol., 30, 2843-2849, doi:10.1021/es960135y, 1996.

Kleffmann, J.: Daytime Sources of Nitrous Acid (HONO) in the Atmospheric Boundary Layer, Chem. Phys. Chem., 8, 1137-1144, doi:10.1002/cphc.200700016, 2007.

Kleffmann, J., Becker, K. H., and Wiesen, P.: Heterogeneous $\mathrm{NO}_{2}$ conversion processes on acid surfaces: possible atmospheric implications, Atmos. Environ., 32, 2721-2729, 1998.

Kleffmann, J., Gavriloaiei, T., Hofzumahaus, A., Holland, F., Koppmann, R., Rupp, L., Schlosser, E., Siese, M., and Wahner, A.: Daytime formation of nitrous acid: A major source of $\mathrm{OH}$ radicals in a forest, Geophys. Res. Lett., 32, L05818, doi:10.1029/2005GL022524, 2005.

Kurtenbach, R., Becker, K. H., Gomes, J. A. G., Kleffmann, J., Lörzer, J. C., Spittler, M., Wiesen, P., Ackermann, R., Geyer, A., and Platt, U.: Investigations of emissions and heterogeneous formation of HONO in a road traffic tunnel, Atmos. Environ., 35, 3385-3394. doi:10.1016/S1352-2310(01)00138-8, 2001.

Lefer, B. and B. Rappenglück: The TexAQS-II radical and aerosol measurement project (TRAMP), Atmos. Environ., 44, 39974004, 2010

Li, S., Matthews, J., and Sinha, A.: Atmospheric Hydroxyl Radical Production from Electronically Excited $\mathrm{NO}_{2}$ and $\mathrm{H}_{2} \mathrm{O}$, Science, 319, 1657-1660, 2008.

Li, S., Matthews, J., and Sinha, A.: Response to Comment on "Atmospheric Hydroxyl Radical Production from Electronically Excited $\mathrm{NO}_{2}$ and $\mathrm{H}_{2} \mathrm{O}$ ", Science, 324, p. 336, doi:10.1126/science.1166877, 2009.
Li, Y., An, J., Min, M., Zhang, W., Wang, F., Xie, P.: Impacts of HONO sources on the air quality in Beijing, Tianjin, and Hebei Province of Chaina, Atmos. Environ., 45, 4735-4744, 2011.

Mao, J., Ren, X., Chen, S., Brune, W. H., Chen, Z., Martinez, M., Harder, H., Lefer, B., Rappenglück, B., Flynn, J., and Leuchner, M.: Atmospheric oxidation capacity in the summer of Houston 2006: Comparison with summer measurements in other metropolitan studies, Atmos. Environ., 44, 4107-4115. doi:10.1016/j.atmosenv.2009.01.013, 2010.

Olaguer, E. P., Kolb, C. E., Lefer, B., Rappenglück, B., Zhang, R., and Pinto, J. P.: Overview of the SHARP campaign: motivation, design, and major outcomes, J. Geophys. Res. Atmos., 118, 5018-5028, doi:10.1002/jgrd.50423, 2013.

Pagsberg, P., Bjergbakke, E., Ratajczak, E., and Sillesen, A.: Kinetics of the gas phase reaction $\mathrm{OH}+\mathrm{NO}(+\mathrm{M}) \rightarrow \mathrm{HONO}(+\mathrm{M})$ and the determination of the UV absorption cross section of HONO, Chem. Phys. Lett., 272, 383-390, 1997.

Perner, D. and Platt, U.: Detection of nitrous acid in the atmosphere by differential optical absorption, Geophys. Res. Lett., 6, 917920, 1979.

Rappenglueck, B., Lubertino,G., Alvarez, S., Golovko, J., Czader, B., and Ackermann, L.: Radical precursors and related species from traffic as observed and modeled at an urban highway junction, J. Air Waste Manage., 63, 1270-1286, doi:10.1080/10962247.2013.822438, 2013.

Sarwar, G., Roselle, S. J., Mathur, R., Appel,W., Dennis, R. L., and Vogel, B.: A comparison of CMAQ HONO predictions with observations from the Northeast Oxidant and Particle Study, Atmos. Environ., 42, 5760-5770, 2008.

Skamarock,W. C. and Klemp, J. B.: A time-split nonhydrostatic atmospheric model for weather research and forecasting applications, J. Comput. Phys., 227, 3465-3485, doi:10.1016/j.jcp.2007.01.037, 2008.

Stemmler, K., Ammann, M., Donders, C., Kleffmann, J., and George, C.: Photosensitizied reduction of nitrogen dioxide on humic acid as a source of nitrous acid, Nature, 440, 195-198, 2006.

Stemmler, K., Ndour, M., Elshorbany, Y., Kleffmann, J., D’Anna, B., George, C., Bohn, B., and Ammann, M.: Light induced conversion of nitrogen dioxide into nitrous acid on submicron humic acid aerosol, Atmos. Chem. Phys., 7, 4237-4248, doi:10.5194/acp-7-4237-2007, 2007.

Wong, K. W., Tsai, C., Lefer, B., Grossberg, N., and Stutz, J.: Modeling of daytime HONO vertical gradients during SHARP 2009, Atmos. Chem. Phys., 13, 3587-3601, doi:10.5194/acp-13-35872013, 2013.

Willmott, C. J.: On the validation of models, Phys. Geogr., 2, 184 194, 1981. 